\title{
PENGARUH PENDEKATAN SCIENTIFIC TERHADAP PENGUASAAN \\ KONSEP SISWA PADA PEMBELAJARAN SUBTEMA LINGKUNGAN TEMPAT TINGGALKU KELAS IV SEKOLAH DASAR
}

\author{
Arya Setya Nugroho \\ Program Studi Pendidikan Dasar, Program Pascasarjana, Universitas negeri Surabaya \\ Email: arya.nugroho15@gmail.com
}

\begin{abstract}
Abstrak
Penguasaan konsep dapat dikembangkan dalam diri siswa tentunya membutuhkan sebuah pembelajaran yang mendukung siswa dalam mengembangkan penguasaan konsep pada siswa itu sendiri. Pembelajaran dirancang untuk menyusun data sehingga konsep-konsep penting dapat dipelajari secara tepat dan efisien. Selain itu pembelajaran memiliki pandangan bahwa para siswa tidak hanya dituntut untuk mampu membentuk konsep melalui proses pengklasifikasian data akan tetapi harus dapat membentuk susunan konsep dengan kemampuannya sendiri. Pengaruh pendekatan scientific diharapkan dapat berpengaruh pada penguasaan konsep siswa. Karena itu peneliti terdorong untuk memberikan pengalaman belajar kepada siswa dengan menerapkan model pembelajaran konsep pada materi seperti menggambarkan satu sosok pekerja yang sesuai dengan deskripsi data diri beserta lingkungan tempat tempat kerja.

Pada penelitian ini, peneliti menggunakan jenis penelitian eksperimen. Penelitian eksperimen dilakukan karena untuk meneliti ada tidaknya hubungan sebab akibat antara variabel terikat dan bebas melalui pendekatan scientific. Populasi penelitian adalah siswa kelas IVA (eksperimen) dan kelas IVB (kontrol) SD Muhammadiyah 1Taman tahun ajaran 2014/2015.

Hasil pengujian hipotesis bahwa nilai t hitung yang didapat yaitu sebesar 8,607 dan nilai signifikansi sebesar 0,000, hasil pengujian hipotesis tersebut menunjukkan bahwa nilai t hitung yang didapat lebih besar dari nilai t dalam tabel $(8,607>1,7011)$ sedangkan nilai signifikansi tersebut lebih kecil dari nilai $\alpha(0,000<0,05)$. Berdasar hasil tersebut, maka hipotesis diterima, artinya terdapat pengaruh yang signifikan antara pendekatan Scientific terahadap penguasaan konsep siswa kelas IV SD Muhammadiyah 1 Taman Sidoarjo.
\end{abstract}

Kata Kunci : : Pendekatan Scientific, Penguasaan Konsep,

\begin{abstract}
Mastery of concepts can be developed in students certainly require a learning support students in developing the students' mastery of the concept itself. Learning is designed to compile data so that important concepts can be studied more precisely and efficiently. Besides learning the view that students are not only required to be capable of forming concepts through data classification process but should be able to establish the composition of the concept on their own. The influence of scientific approach is expected to affect the students' mastery of concepts. Therefore, researchers are encouraged to provide a learning experience to students by applying the learning model illustrates the concept of the material as a figure of workers who fit the description of the data themselves and their environment in the workplace.

In this study, researchers used a kind of experimental research. Experimental research carried out due to examine whether there is a causal relationship between the dependent and independent variables through a scientific approach. The study population is the class IVA (experimental) and IVB class (control) SD Muhammadiyah 1 Taman academic year 2014/2015.

Results of testing the hypothesis that $\mathrm{t}$ value obtained is equal to 8,607 and a significance value of 0.000 , the hypothesis testing results show that the $\mathrm{t}$ value obtained is greater than the value of $\mathrm{t}$ in the table $(8,607>1.7011)$, while the significance value smaller than the value of $\alpha(0.000<0.05)$. Based on these results, the hypothesis is accepted, meaning that a significant difference between the approach Scientific about control concept of the student class IV SD Muhammadiyah 1 Taman Sidoarjo
\end{abstract}

Keywords : Scientific Approach, Control Concepts 


\section{PENDAHULUAN}

Peraturan Pemerintah Bab IV Pasal 19 No. 19

Tahun 2005 menyatakan bahwa proses pembelajaran pada satuan pendidikan diselenggarakan secara interaktif, inspiratif, menyenangkan, menantang, memotivasi peserta didik untuk dapat berpartisipasi aktif, serta minat, dan perkembangan fisik, serta psikologis peserta didik. Sesuai dengan peraturan pemerintah tersebut dalam hal ini siswa harus memelajari ide-ide, memecahkan masalah, menerapkan hal-hal yang telah mereka pelajari, menyampaikan gagasan, melakukan percobaan, dan melakukan pengamatan.

Namun kenyataan yang terjadi di lapangan, terdapat kekurangan yang dilakukan oleh guru pada saat pembelajaran yaitu: (1) guru pada saat memberikan materi masih bersifat tradisional, (2) guru kurang memahami karakteristik dari berbagai model-model pembelajaran yang ada, hanya menyusun Rencana Pelaksanaan Pembelajaran (RPP) tanpa memperhatikan dimensi pembelajaran yang ada., (3) guru memberikan materi sebatas materi yang ada pada buku, (4) guru mendominasi pembelajaran, sehingga pembelajaran berpusat pada guru, 5) guru dalam menyampaikan pembelajaran dengan materi-materi konsep dengan secara langsung.

Dengan demikian proses pembelajaran berlangsung kaku, sehingga kurang mendukung pengembangan pengetahuan, sikap, keterampilan, dan penguasaan siswa. Pada saat pembelajaran berlangsung, siswa mengalami kendala-kendala: (1) aktivitas siswa cenderung pasif di dalam kelas, (2) siswa kurang termotivasi mengikuti proses pembelajaran, (3) siswa kurang mampu mengingat materi yang diberikan oleh guru, (4) siswa tidak dapat membedakan dan mengelompokkan materi yang diberikan guru, (5) siswa hanya mencatat dan menghafalkan materi konsep dari guru.

Penguasaan konsep dapat dikembangkan dalam diri siswa tentunya membutuhkan sebuah pembelajaran yang mendukung siswa dalam mengembangkan penguasaan konsep pada siswa itu sendiri. Pembelajaran dirancang untuk menyusun data sehingga konsep-konsep penting dapat dipelajari secara tepat dan efisien. Selain itu pembelajaran memiliki pandangan bahwa para siswa tidak hanya dituntut untuk mampu membentuk konsep melalui proses pengklasifikasian data akan tetapi harus dapat membentuk susunan konsep dengan kemampuannya sendiri (Aunurrahman, 2009:158)
Pengaruh pendekatan scientific diharapkan dapat berpengaruh pada penguasaan konsep siswa. Karena itu peneliti terdorong untuk memberikan pengalaman belajar kepada siswa dengan menerapkan model pembelajaran konsep pada materi seperti menggambarkan satu sosok pekerja yang sesuai dengan deskripsi data diri beserta lingkungan tempat tempat kerja. Materi yang dipilih diharapkan dapat memberikan kesempatan dalam meningkatkan kemampuan siswa untuk belajar menemukan sendiri. Selanjutnya melalui pembelajaran ini diharapkan dapat meningkatkan penguasaan konsep siswa pada mata pelajaran IPS. Pendekatan scientific yang diterapkaan pada kurikulum 2013 pada SD tidak lagi mengenal mata pelajaran dan tidak lagi mengenal bidang studi, artinya mata pelajaran dan semua bidang studi terintegrasi dalam bentuk masalah atau unit. Batasbatas antara mata pelajaran dan bidang studi tidak terlihat lagi. Jadi, semua mata pelajaran telah menjadi suatu kesatuan yang utuh. Sehingga, di SD yang sudah menerapkan Kurikulum 2013 kecuali kelas III dan VI, siswa diberi materi pelajaran berdasarkan tema-tema yang terintegrasi. Tema merupakan alat atau wadah untuk mengedepankan berbagai konsep kepada anak didik secara utuh (Hidayat, 2013).

\section{METODE}

Pada penelitian ini, peneliti menggunakan jenis penelitian eksperimen. Penelitian eksperimen dilakukan karena untuk meneliti ada tidaknya hubungan sebab akibat antara variabel terikat dan bebas melalui pendekatan scientific. Peneliti akan mengujicobakan penelitiannya ke dalam kelas kontrol dan kelas eksperimen. Pada kelas kontrol akan menerapkan pembelajaran konvensional (tidak mendapat perlakuan) dan pada kelas eksperimen akan menerapkan pendekatan scientific.

Waktu yang dialokasikan untuk penelitian ini adalah selama semester genap 2014/2015. Tempat penelitian di SD Muhammadiyah 1 Taman. Pemilihan SD Muhammadiyah 1-2 Taman sebagai tempat penelitian berdasarkan pertimbanganpertimbangan : (1) sekolah bersifat terbuka dan mau menerima upaya inovasi terhadap pendidikan, (2) kesediaan dari pihak sekolah (kepala sekolah, guru, dan murid) untuk bekerjasama dalam kegiatan penelitian, dan (3) memiliki kelas paralel sehingga memudahkan untuk pengelompokan kelas kontrol dan kelas eksperimen.

Populasi penelitian adalah siswa kelas IVA (eksperimen) dan kelas IVB (kontrol) SD 
Muhammadiyah 1 Taman tahun ajaran 2014/2015. Sampel penelitian adalah 20 siswa untuk masuk kelas kontrol dan 20 siswa untuk masuk kelas eksperimen.

Pada penelitian ini untuk penilaian penguasaan konsep menggunakan instrumen tes objektif dan uraian. Tes digunakan untuk mengukur tingkat penguasaan konsep siswa sebelum pembelajaran (pretest) dan sesudah pembelajaran (posttest). Tes yang disusun berupa tes tertulis.

Sebelum tes objektif digunakan mengambi data, soal tes diujicobakan kepada siswa di luar sampel. Setelah itu, dilakukan uji validitas, uji reliabilitas. Dan untuk teknik analisis data menggunakan uji normalitas, uji homogenitas dan uji t-tes. Hal ini dimaksudkan untuk mendapatan soal yang layak untuk dijadikan instrumen penelitian.

\section{KAJIAN TEORI}

Pembelajaran saintifik merupakan pembelajaran yang mengadopsi langkah-langkah scientist dalam membangun pengetahuan melalui metode ilmiah. Develop pembelajaran yang diperlukan adalah yang memungkinkan terbudayakannya kecakapan berpikir sains, terkembangkannya "implication of investigation" dan kemampuan berpikir kreatif siswa (Alfred De Vito, 1989).

Pembelajaran dengan pendekatan saintifik adalah proses pembelajaran yang dirancang sedemikian rupa agar peserta didik secara aktif mengonstruk konsep, hukum atau prinsip melalui tahapan-tahapan mengamati (untuk mengidentifikasi atau menemukan masalah), merumuskan masalah, mengajukan atau merumuskan hipotesis, mengumpulkan data dengan berbagai teknik, menganalisis data, menarik kesimpulan dan mengomunikasikan konsep, hukum atau prinsip yang "ditemukan". Pendekatan saintifik dimaksudkan untuk memberikan pemahaman kepada peserta didik dalam mengenal, memahami berbagai materi menggunakan pendekatan ilmiah, bahwa informasi bisa berasal dari mana saja, kapan saja, tidak bergantung pada informasi searah dari guru.

Pendekatan scientific dengan demikian mengkaji cara-cara untuk mendapat pengetahuan baru yang dipelajari dengan menggunakan proses yang sistimatis. Proses sistimatis ini memadukan dua penalaran yakni penalaran deduktif dan penalaran induktif. Penggunaan pendekatan scieintific dalam pembelajaran mem-bawa iklim berpikir rasional yakni mendasarkan kesimpulan pada kecerdasan, logika dan bukti empiric (Sujarwanto, 2005:128).

Menurut Permendikbud Nomor 81 A Tahun

2013 Lampiran IV, proses pembelajaran terdiri atas lima pengalaman belajar pokok yaitu mengamati, menanya, mengumpulkan informasi/ eksperimen, mengasosiasikan/ mengolah informasi, dan mengkomunikasikan. Kurikulum 2013 menekankan pada dimensi pedagogik modern dalam pembelajaran, yaitu menggunakan pendekatan ilmiah. Pendekatan ilmiah (scientific appoach) dalam pembelajaran sebagaimana dimaksud meliputi mengamati, menanya, mencoba, mengolah, menyajikan, menyimpulkan, dan mencipta untuk semua mata pelajaran. Melalui pendekatan ilmiah akan memberikan proses atau kegiatan belajar yang bermakna, karena pada tahapan scientific siswa akan dihadapkan dengan hal yang nyata. Hal ini dapat membantu siswa untuk mudah mengikuti kegiatan pelajar dan mampu memahaminya.

Menurut Sapriya (2012:63) konsep merupakan pokok pengertian yang bersifat abstrak yang menghubungkan orang dengan kelompok benda, peristiwa, atau pemikiran. Lahirnya konsep karena adanya kesadaran atas atribut kelas yang ditunjukkan oleh simbol. Disamping itu menurut B. Othanel Smith dan Robert H Ennis (dalam Wahab, 2012:127) yang dimaksud konsep adalah kumpulan pengertian abstrak yang berkaitan dengan symbol untuk kelas dari suatu benda, kejadian atau gagasan.

Menurut Rosser (dalam Dahar, 2006:63) konsep adalah suatu abstraksi yang mewakili satu kelas objek, kejadian, kegiatan, atau hubungan yang mempunyai atribut yang sama. Konsep merupakan suatu abstraksi mental yang mewakili satu kelas stimulus (Dahar, 2006:62). Disamping itu menurut Moore (dalam Skeel, 1995:159) konsep adalah sesuatu yang dipahami dalam pikiran-pikiran, sebuah pemikiran, sebuah gagasan atau pendapat. Menurut Vygotsky (dalam Adisusilo, 2012: 175) membedakan dua macam konsep, yaitu konsep spontan dan konsep ilmiah. Konsep spontan diperoleh peserta didik dari kehidupan sehari-hari dan konsep ilmiah diperoleh dari pelajaran di sekolah.

Untuk mata pelajaran, materi, atau situasi tertentu, sangat mungkin pendekatan ilmiah ini tidak selalu tepat diaplikasikan secara prosedural. Pada kondisi seperti ini, tentu saja proses pembelajaran harus tetap menerapkan nilai-nilai atau sifat-sifat ilmiah dan menghindari nilai-nilai atau sifat-sifat nonilmiah. Siswa harus dapat mengkonseptualkan 
dan mengembangkan konsep mereka sendiri tidak hanya mengerti nama dari sebuah konsep. Sebagaimana yang dikatakan oleh Beyer (dalam Skeel, 1995),

Konsep akan membantu kita dalam mengorganisir data menjadi pola-pola yang dapat menyediakan penguasaan yang berarti mengenai data tersebut. Yang berarti, bahwa mereka akan menyediakan sebuah kategorikategori yang saling berhubungan (interrelated) dimana bukti-bukti akan dikumpulkan dari data atau dari pengalaman. Konsep juga akan dapat menghasilkan pertanyaan-pertanyaan yang dapat diajukan terhadap data untuk menemukan bukti dari kategori-kategori yang telah dibuat. Dengan mengetahui sebuah konsep maka akan dapat membuat kita dapat menggunakan elemenelemennya untuk membentuk sebuah pertanyaan guna menyelidiki sebuah data.

Taba (dalam Skeel. 1995:161) menegaskan bahwa konsep akan terbentuk ketika siswa menjawab pertanyaan yang mengharuskan siswa untuk : a) menyebutkan item-item, b) menemukan sebuah basis dalam pengelompokan item-item dengan cara tertentu, c) mengidentifikasi karakteristik yang sama dari sebuah item, d) melabeli sebuah kelompok, e) menggolongkan itemitem yang telah mereka sebutkan melalui sebuah tabel. Untuk memahami konsep lebih jauh, siswa akan bergerak dalam tahap penginterpretasian data dan pengaplikasian data.

Seperti yang diuraikan diatas bahwa penguasaan konsep memegang peranan penting dalam hidup manusia. Tanpa penguasaan konsep yang benar, seseorang akan salah dalam menilai sesuatu atau juga salah dalam melakukan suatu hal di karenakan tidak mampu memilah konsep dengan benar. Dalam penguasaan konsep perlu adanya pendekatan konsep sebagai berikut:

a. Pendekatan kognitif

Pendekatan kognitif tentang belajar memusatkan pada proses pemerolehan dalam sifat konsep dan bagaimana konsep itu disajikan dalam struktur kognitif (Dahar, 2006:66). Hal ini dikarenakan dua alasan yaitu: (1) konsep konjungtif lebih mudah dipelajari dari pada konsep disjungtif atau konsep relasional, dan (2) belajar konsep lebih mudah dengan menggunakan paradigm selektif dari pada paradigm reseptif b. Pendekatan dewasa ini

Pendekatan yang digunakan didasarkan pada kombinasi teknik induktif dan deduktif. Penggunaan teknik kombinasi dipandang lebih baik dari pada hanya menggunakan satu teknik saja (Dahar, 2006:66). Sehingga dengan menggunakan kombinasi tersebut pendekatan konsep akan lebih efektif.

Ausubel (dalam Dahar, 2006:64) menyatakan, konsep diperoleh dengan 2 cara yaitu pembentukan konsep dan asimilasi konsep. Pembentukan konsep merupakan bentuk pemerolehan konsep sebelum anak masuk sekolah. Asimilasi konsep merupakan cara utama untuk memperoleh konsep selama dan sesudah sekolah.

a. Pembentukan konsep

Pembentukan konsep merupakan proses induktif. Bila anak dihadapkan pada stimulus lingkungan, ia mengabstraksi sifat atau atribut tertentu yang sama dari berbagai stimulus.

b. Asimilasi konsep

Asimilasi konsep bersifat deduktif, bahwa seseorang akan belajar arti konseptual baru dengan memperoleh penyajian atribut-atribut kriteria konsep, kemudian mereka akan menghubungjan atribut-atribut ini dengan gagasan-gagasan yang relevan yang sudah ada dalam struktur kognitif mereka.

Menurut Sriyanto (2007) menjelaskan bahwa lingkungan hidup adalah ruang yang ditempati oleh suatu makhluk hidup bersama dengan benda hidup dan benda tak hidup. Lingkungan hidup didasarkan pada pada konsep ekologi yaitu ilmu tentang hubungan timbal balik antara makhluk hidup dengan lingkungan hidupnya (dalam Riberu 2002: 127). Keberadaan lingkungan hidup sangatlah penting bagi kehidupan manusia. Apabila terjadi kerusakan lingkungan hidup maka kehidupan manusia juga akan terganggu.

Pada kurikulum 2013 hubungan lingkungan dengan makhluk hidup di sekitarnyaa juga terdapat pada subtema lingkungan tempat tinggalku tema tempat tinggal di kelas IV yang terintegrasikan satu bidang studi dengan bidang studi lainnya. Dalam subtema ini mencakup materi IPS dan Matematika yang terangkum dalam subtema lingkungan tempat tinggalku pembelajaran satu. Setiap materi yang dipadukan berisi materi IPS 4 kompetensi dasar dan Matematika 3 kompetensi dasar. Hal ini terbentuk jaringan tema yang saling berhubungan. Sesuai dengan Trianto (2010:148) jaringan tema adalah pola hubungan antara tema tertentu dengan su-sub 
pokok bahasan yang diambil dari berbagai bidang studi terkait. Dengan terbentuknya jaringan tema diharapkan peserta didik memahami satu tema tertentu dengan melakukan pendekatan interdisiplin berbagai bidang ilmu pengetahuan.

\section{HASIL DAN PEMBAHASAN}

Secara sederhana pendekatan ilmiah merupakan suatu cara atau mekanisme untuk mendapatkan pengetahuan dengan prosedur yang didasarkan pada suatu metode ilmiah. Proses pembelajaran harus terhindar dari sifat-sifat atau nilai-nilai non ilmiah. Pendekatan non ilmiah dimaksud meliputi semata-mata berdasarkan intuisi, akal sehat, prasangka, penemuan melalui coba-coba, dan asal berpikir kritis. Perubahan proses pembelajaran (dari siswa diberi tahu menjadi siswa mencari tahu) dan proses penilaian (dari berbasis output menjadi berbasis proses dan output). Penilaian proses pembelajaran menggunakan pendekatan penilaian otentik (authentic assesment) yang menilai kesiapan siswa, proses, dan hasil belajar secara utuh (Permen No. 65 Tahun 2013).

Berdasar hasil penilaian terhadap penerapan model pembelajaran dengan pendekatan Scientific baik antara kelas kontrol maupun kelas eksperimen termasuk dalam kategori baik. Hal tesebut menunjukkan bahwa siswa kelas kontrol maupun kelas eksperimen dapat mengikuti kegiatan belajar mengajar dengan pendekatan Scientific dapat dikategorikan baik. Akan tetapi terdapat perbedaan pencapaian prosentase antara kelas kontrol dengan kelas eksperimen, untuk kelas ontrol persentase yang dicapai yaitu sebesar $65,07 \%$ dan untuk kelas eksperimen yaitu sebesar $74,53 \%$. Dengan demikian dalam memahami atau mengikuti kegiatan pembelajaran dengan pendekatan Scientific siswasiswa kelas eksperimen lebih baik dibandingkan dengan siswa-siswa kelas kontrol.

Konsep merupakan salah satu pengetahuan awal yang harus dimiliki siswa karena konsep merupakan dasar dalam merumuskan prinsipprinsip. Penguasaan konsep yang baik akan membantu pemakaian konsep-konsep yang lebih kompleks. Penguasaan konsep adalah kemampuan siswa menguasai materi pelajaran yang diberikan. Penguasaan konsep merupakan dasar dari penguasaan prinsip-prinsip teori, artinya untuk dapat menguasai prinsip dan teori harus dikuasai terlebih dahulu konsep-konsep yang menyusun prinsip dan teori yang bersangkutan. Untuk mengetahui sejauh mana penguasaan konsep dan keberhasilan siswa, maka diperlukan tes yang akan dinyatakan dalam bentuk angka atau nilai tertentu. Penguasaan konsep juga merupakan suatu upaya ke arah pemahaman siswa untuk memahami hal-hal lain di luar pengetahuan sebelumnya. Jadi, siswa di tuntut untuk menguasai materi-materi pelajaran selanjutnya.

Nilai rata-rata yang dicapai kelas eksperimen pada pre test yaitu 56,94 sedangkan untuk kelas kontrol diperoleh rata-rata nilai yaitu 56,24 . Sedangkan untuk rata-rata nilai post test untuk kelas eksperimen yaitu 88,82 kemudian nilai rata-rata post test untuk kelas kontrol yaitu 60,18. Dengan demikian nilai pre test dan post test yang dicapai oleh kelas eksperimen lebih baik dari nilai pre test dan post test yang dicapai siswa kelas kontrol. Kemudian rata - rata nilai post test yang dicapai kelas eksperimen mengalami peningkatan pada rata-rata nilai pre test dari 56,94 menjadi 88,82. Sedangkan untuk kelas kontrol juga mengalami peningkatan, rata-rata nilai pada pre test 56,24 menjadi 60,18 pada post test. Berdasarkan rata-rata nilai yang dicapai oleh siswa, terbukti pada kelas eksperimen mengalami peningkatan yang signifikan.

Instrumen memiliki validitas dapat memberikan hasil ukur yang tepat dan akurat sesuai dengan maksud dikenakannya instrumen tersebut. Pengukuran validitas menggunakan korelasi product moment antara skor butir dengan skor skalanya. Koefisien korelasi (r) dapat dianggap memuaskan atau dianggap valid apabila nilai $r$ hitung lebih besar dari $\mathrm{r}$ tabel. Berdasarkan uji validitas pendekatan Scientific dan uji validitas penguasaan konsep, menunjukkan bahwa nilai $\mathrm{r}$ hitung (koefisien korelasi) lebih besar dari nilai $r$ tabel. Dengan demikian bahwa instrument penelitian yang digunakan untuk mengukur variabel dapat dikatakan valid.

Pada uji realibilitas untuk menguji alat ukur yang digunakan menggunakan uji reliabilitas dengan metode Alpha Cronbach. Pendekatan scientific nilai Alpha Cronbach dari pre test dan post test pendekatan scientific memiliki nilai lebih dari nilai Min Cronbach's yang disyaratkan yaitu 0,7 dengan demikian semua item baik pre test dan post test dalam pendekatan scientific adalah reliable (andal). Berdasarkan data uji relibilitas penguasaan konsep nilai Alpha Cronbach dari pre test dan post test Penguasaan konsep memiliki nilai lebih dari nilai Min Cronbach's yang disyaratkan yaitu 0,7 dengan demikian semua item baik pre test dan post test dalam Penguasaan konsep adalah reliable (andal).

Data penelitian harus diuji kenormalannya menggunakan uji normalitas. Berdasarkan hasil uji 
normalitas pendekatan scientific, diketahui bahwa nilai signifikansi (Asymp. Sig.) dari pendekatan scientific sebesar $(0,599 ; 0,810 ; 0,426$; dan 0,474) lebih besar dari 0,05 , sehingga disimpulkan bahwa data pendekatan scientific yang diuji normalitas terdistribusi secara normal. Berdasarkan output uji normalitas untuk penguasaan konsep dengan dasar pengambilan keputusan dalam uji normalitas, diketahui bahwa nilai signifikansi dari penguasaan konsep Siswa sebesar $(0,706 ; 0,627 ; 0,434$; dan 0,992 ) lebih besar dari 0,05 , sehingga disimpulkan bahwa data penguasaan konsep siswa yang diuji terdistribusi secara normal.

Dalam uji homogenitas digunakan sebagai bahan acuan untuk menentukan keputusan uji statistik. Berdasarkan output SPSS untuk uji homoginitas diketahui bahwa nilai signifikansi varibel penguasaan konsep Siswa $(\mathrm{Y})$ berdasarkan variabel Pendekatan scientific $(\mathrm{X})=0,633>0,05$ untuk kelas eksperimen dan 0,219>0,05 untuk kelas kontrol, artinya data varibel Penguasaan konsep siswa $(\mathrm{Y})$ berdasarkan variabel Pendekatan scientific (X) baik untuk kelas eksperimen maupun kelas kontrol mempuyai varian yang sama.

Berdasar hasil pengujian hipotesis diperoleh hasil $\mathrm{t}$ hitung sebesar 8,607 dan nilai signifikansi sebesar 0,000 . Dengan demikian demikian nilai t hitung yang didapat lebih besar dari nilai t dalam tabel $(8,607>1,7011)$ sedangkan nilai signifikansi tersebut lebih kecil dari nilai $\alpha(0,000<$ 0,05). Berdasar hasil tersebut, maka hipotesis diterima, artinya terdapat pengaruh yang signifikan antara pendekatan Scientific terahadap pendekatan konsep siswa kelas IV SD Muhammadiyah 1 Taman Sidoarjo.

Dari data di atas dapat diketahui bahwa aktivitas guru menggunakan pendekatan scientific mengalami kemajuan dan mencapai hasil yang terbaik pada penguasaan konsep siswa, hal yang paling penting untuk diperhatikan adalah membangun keaktifan siswa melalui diskusi kelompok dan menanamkan lebih dalam ke dalam ingatan siswa mengenai materi yang dipelajari halini sesuai dengan asimilasi konsep menurut Ausubel (dalam Dahar, 2011: 65) dalam proses ini anakanak diberi nama konsep dan atribut konsep itu.

Ini berarti bahwa mereka akan belajar arti konseptual baru dengan memperoleh penyajian atribut-atribut kriteria konsep, kemudian mereka akan menghubungkan atribut-atribut ini dengan gagasan-gagasan relevan yang sudah adadalam struktur kognitif mereka. Hal itu terbukti dengan aktivitas bimbingan guru dalam membimbing siswa mempelajari konsep dan menanamkan konsep pada siswa. Sehingga mengakibatkan kemampuan konsep pada siswa meningkat dilihat dari persentase keberhasilan tiap tahapan.

Dengan menerapkan pendekatan scientific diharapkan aktivitas siswa secara aktif dalam proses pembelajaran. Berdasarkan hasil penelitian, terlihat pada aktivitas siswa melakukan kegiatan awal pembelajaran siswa sangat aktif terbukti dengan nilai yang selalu konstan pada tiap-tiap tahapan. Hal ini dipengaruhi bimbingan guru yang baik disaat kegiatan awal, sehingga siswa duduk dengan rapi, menjawab salam dari guru dengan semangat, berdoa bersama-sama, dan mendengarkan saat diabsen. Sedangkan pada aspek siswa melakukan ice breaking dan menanggapi apresepsi siswa lebih demokrasi dalam memberikan respon dilihat dari tiap siklus mengalami peningkatan.

\section{PENUTUP}

\section{Kesimpulan}

Berdasarkan hasil penelitian dan analisis yang dilakukan, maka diperoleh kesimpulan bahwa terdapat perbedaan yang signifikan antara anak yang mendapat perlakuan dengan kegiatan pendekatan scientific terhadap penguasaan konsep dengan anak yang tidak diberi dengan kegiatan pendekatan scientific. Hal ini didasarkan pada peningkatan nilai rata-rata kelompok eksperimen yang mendapat perlakuan dengan pendekatan scientific dalam penguasaan konsep. Dengan demikian pendekatan scinetific berpengaruh terhadap penguasaan konsep siswa sekolah dasar.

\section{Saran}

Terkait dengan hasil penelitian ini, maka beberapa saran yang perlu peneliti sampaikan adalah

1. Guru hendaknya menerapkan model pembelajaran konsep, khususnya pada materi konsep. Karena lebihefektif dalam menyebutkan, menggolongkan, mengidentifikasi, dan menyimpulkan materi yang berhubungan dengan konsep. Apabila dengan menggunakan benda konkret dalam pembelajaran lebih bermakna dalam mempelajari materi konsep.

2. Guru hendaknya memfasilitasi siswa dalam pembelajaran dengan menggunakan model pembelajaran konsep, agar siswa menjadi lebih aktif dalam pembelajaran seperti memberikan reward pada proses pembelajaran, mengajak siswa keluar kelas untuk melakukan pengamatan, pendemonstrasian bendakonkret, dan melatih 
kerjasama dalam kelompok. Padaakhirnya aktivitas siswa pada saat proses pembelajaran berlangsung menjadi hidup dan berkembang.

3. Evaluasi yang diberikan pada siswa, hendaknya lebihmemenuhi materi yang berkenaan konsep dandisesuaikan dengan materi yang ada. Dalam pembuatansoal evaluasi harus lebih menggunakan bahasa yangmudah dipahami oleh siswa. Selain itu dalam proses pembelajaran yang pada akhirnya mengarah padaevaluasi, guru lebih memahami dan memaknai bagaimana mengajarkan materi konsep yang baik padasiswa. Seperti dengan mendemonstrasikan benda yangkonkret. Hal ini terbukti pada saat guru memfasilitasisiswa untuk mendemonstrasikan benda konkret yang disediakan oleh guru dan pada hasil belajar penguasaankonsep yang meningkat.

\section{DAFTAR PUSTAKA}

Adisusilo, Sutarjo. (2012). Pembelajaran NilaiKarakter Konstruktivisme dan VCT sebagai Inovasi Pendekatan Pembelajaran Afektif. Jakarta: PT RajaGrafindo Persada

Al-Habil, Wasim. (2010). The development of the concept of the "one best method" in public administration. Vol 2 No. 6 tahun 2010 pp. 96-102

Arifin, Zainal. (2011). Penelitian Pendidikan Metode dan Paradigma Baru. Bandung: PT Remaja Rosdakarya

Arikunto, Suharsimi. (1989). Manajemen Penelitian. Jakarta: Departemen Pendidikan dan Kebudayaan P2LPTK

Aunurrahman. (2011). Belajar dan Pembelajaran. Bandung: Alfabeta

Badan Pengembangan Sumber Daya Manusia Pendidikan dan Kebudayaan dan Penjaminan Mutu Pendidikan, Depdikbud. (2014). Materi Pelatihan Guru Implementasi Kurikulum 2013 Tahun 2014 SD Kelas 1. Jakarta: Depdikbud

Dahar, Ratna Wilis. (2011). Teori-teri belajar \& Pembelajaran. Jakarta: Penerbit Erlangga

Kemdikbud. (2013). Pengembangan Kurikulum 2013. Paparan Mendikbud dalam Sosialisasi Kurikulum 2013. Jakarta :Kemdikbud

Riberu, Paskalis. (2002). Pembelajaran Ekologi. Vol. 1 No. 01 UNJ

Sabahiyah. (2013). Pengaruh Model Pembelajaran Inkuiri Terbimbing Terhadap Keterampilan Proses Sains dan Penguasaan Konsep IPA Siswa Kelas $V$ Gugus 03 Wanasaba Lombok Timur. Vol 3 No. 5 tahun 2013
Sapriya. (2012). Pendidikan IPS Konsep dan Pembelajaran. Bandung: PT Remaja Rosdakarya

Skeel, Dorothy J. (1995). Elementary Social Studies Challenges for Tomorrow's World. USA: Harcourt Brace College Publishers

Sujarwanto, Agus. (2005). Ikhtiar $\mathrm{Ke}$ arah Implementasi Pendekatan Saintific (scientific approach) dalam Pembelajaran di Sekolah. Prosiding, FKIP UM Metro, 126-137

Trianto. (2011). Panduan Lengkap Penelitian Tindakan Kelas (classroom Action Research) teori dan Praktek. Jakarta: Prestasi Pustakarya

Wahab, Abdul Aziz. (2012). Metode dan Modelmodel Mengajar Ilmu Pengetahuan Sosial (IPS). Bandung: Penerbit Alfabeta 